\title{
Antibacterial and hypoglycemic activity in vitro of polysaccharide obtained from
}

\section{Periconia byssoides}

\author{
Atividade antibacteriana e hipoglicêmica in vitro do polissacarídeo obtidlo de Periconia byssoides \\ Actividad antibacteriana e hipoglucemiante in vitro del polisacárido obtenido de Periconia \\ byssoides
}

\begin{abstract}
Fungi are source of polysaccharides that can show biological activity. The objective of this research was obtained polysaccharides from Periconia byssoides and evaluate antibacterial and hypoglycemic activity in vitro. The numberaverage molecular weight and degree of polymerization were determined. The results show that the polysaccharide of $P$. byssoides has potential as hypoglycemic. Therefore, it would be interesting to conduct in vivo research with this polysaccharide, to know about its hypoglycemic activity.
\end{abstract}

Keywords: $P$. byssoides; Extraction; $\alpha$-amylase; Antibacterial.

\section{Resumo}

Os fungos podem produzir polissacarídeos, que podem apresentar atividade biológica. O objetivo desta pesquisa foi obter polissacarídeos de Periconia byssoides e avaliar a atividade antibacteriana e hipoglicêmica in vitro. A massa molecular média e grau de polimerização foram determinados. Os resultados mostram que o polissacarídeo de $P$. byssoides tem potencial como hipoglicemiante. Portanto, seria interessante realizar pesquisas in vivo com esse polissacarídeo, para conhecer sua atividade hipoglicêmica.

Palavras-chave: P. byssoides; Extração; $\alpha$-amylase; Antibacteriano.

\section{Resumen}

Los hongos pueden producir polisacáridos que pueden tener actividad biológica. El objetivo de esta investigación fue obtener polisacáridos de Periconia byssoides y evaluar la actividad antibacteriana e hipoglucemiante in vitro. Se determinaron la masa molecular y el grado de polimerización. Los resultados muestran que el polisacárido de $P$. byssoides tiene potencial como agente hipoglucemiante. Por tanto, sería interesante realizar una investigación in vivo con este polisacárido, para conocer su actividad hipoglucemiante.

Palabras clave: $P$. byssoides; Extracción; $\alpha$-amilasa; Antibacteriano.

\section{Introduction}

The use of natural polysaccharides in the industry's food, pharmaceutical and cosmetics have increased considerably in recent years, being used in the form of additives, bio-absorbents, metal removal agents, bio-flocculants, delivery agents of medicaments, among other functions (De Vuyst et al., 2001; Welman and Maddox, 2003; Badel et al., 2011; Wasser, 2015) and micro-organisms, such as bacteria, fungi and algae, have shown a high capacity to synthesize and excrete polysaccharides (Wang et al., 2010; Badel et al., 2011). From microorganisms is possible to obtain exopolysaccharides or cell wall polysaccharides (Mahapatra \& Banerjee, 2013; Wang et al., 2017). 
Numerous studies have shown that natural polysaccharides have a plethora of pharmacological activities, such as antitumor (Cardoso et al., 2013; Fu et al., 2015; Liu et al., 2014; Sharma et al., 2016; Yu et al., 2017), immunomodulatory (Fukuda et al., 2009; Sharma et al., 2016), anti-inflammatory (Cheng et al., 2016; Du et al., 2015), antioxidants (Ebrahimiasl et al., 2015; Kumar et al., 2015; Raveendran et al., 2015; Giese et al., 2015; Maity et al., 2015; Wang et al., 2017; Tian et al., 2016), anticoagulant (Vasconcelos et al., 2013; Ehmann et al., 2015; Ye et al., 2012), hypoglycemic (Lazaridou et al. 2014; Sharafbafi et al. 2014), antiparasitic (Noleto et al., 2002; Barroso et al., 2007; Oliveira et al., 2012; Nogueira et al., 2014), among others.

The fungus Periconia byssoides was first isolated from the marine species Aplysia kurodai (Yamada et al., 2007). Subsequently, research with active metabolites of this fungal species identified cell adhering inhibitors (Yamada et al., 2005), that demonstrated significant inhibition on human cancer cells (Yamada et al., 2007).

Therefore, the objective of this research was obtained polysaccharides from Periconia byssoides and evaluate its antibacterial and hypoglycemic activity in vitro.

\section{Methodology}

\subsection{Micro-organism}

The fungus Periconia byssoides (CCMB 07.07) was obtained from the Collection of Cultures of Micro-organisms of Bahia (UEFS) and was maintained in BDA agar medium at $28^{\circ} \mathrm{C}$ in an incubator (IGO 150 Cell Life - Jouan).

\subsection{Cultivation conditions}

The fungus Periconia byssoides was cultivated in BDA medium for a period of 20 days at $28^{\circ} \mathrm{C}$ for biomass production. After, fungal mycelium discs $(\sim 1 \mathrm{~cm})$ were transferred to Erlenmeyer flasks containing $100 \mathrm{~mL}$ of liquid culture medium (malt $2 \%$, peptone $1 \%$ and glucose $2 \%$ ). The vials were placed in agitation at 120 rpm in a rotary agitator. After 15 days, the medium was filtered and centrifuged (Centrifuge 5804R - Eppendorf, São Paulo, Brazil) at 8000 x g for 15 min at 4 ${ }^{\circ} \mathrm{C}$, and the precipitate, which contained biomass of P. byssoides, used to extract polysaccharides (Dong et al. 2009).

\subsection{Polysaccharide extraction}

Forty $\mathrm{mL}$ of a $0.1 \mathrm{M}$ sodium hydroxide $(\mathrm{NaOH})$ solution was added to $2.0 \mathrm{~g}$ of dry biomass $(20 \mathrm{~mL} / \mathrm{g})$ and heated in a water bath at $100^{\circ} \mathrm{C}$ for 10 minutes. After the incubation time, the material was centrifuged at $9000 \mathrm{~g}$ for $15 \mathrm{~min}$ and the soluble polysaccharide in the alkaline solution was dried at $55^{\circ} \mathrm{C}$ until constant weight.

\subsection{Purification of polysaccharide}

A polysaccharide solution $(15 \mathrm{mg} / \mathrm{mL}$ ) was applied to a column of Sephacryl S-200 (Amersham Bioscience, USA) $(48 \times 1.2 \mathrm{~cm})$ previously balanced with sodium phosphate buffer $(0.05 \mathrm{M}, \mathrm{pH} 7.0)$, which was used to elude the product. Fractions of $2.5 \mathrm{~mL}$ were collected and analyzed for polysaccharide totals by the phenol-sulfuric acid method (Dubois et.al, 1956).

\subsection{The number-average molecular weight (MWn) and degree of polymerization (DPn)}

The number-average molecular weight (MWn) and degree of polymerization (DPn) were determined by the measurement of the sugar reduction value by means of the 3.5-dinitrosaliclic (DNS) method (Miller, 1959) and the total carbohydrate dosage by the sulfuric phenol-acid method (Dubois, 1956), DPn $=[($ total carbohydrates in $\mu \mathrm{g}$ of D- 
glucose $) /($ reducing value in $\mu \mathrm{g}$ of maltose $)] \times 1.9 ; \mathrm{MWn}=[(\mathrm{DPn}) \times 162]+18$ (Vettoriet al., 2012)., according to Vettori et al. (2012).

\subsection{Inhibition of amylase activity}

For this assay, sodium phosphate buffer solution $20 \mathrm{mM}, \mathrm{pH}$ 7.0, $\alpha$-pancreatic pork amylase solution (Type VI, Sigma Aldrich) $(0.5 \mathrm{mg} / \mathrm{mL})$, starch substrate solution (Kit Amylase, Bioclin), color reagent solution, $\mathrm{H}_{2} \mathrm{O}$-solubilized samples), or a positive control (acarbose) were incubated before determining the residual amylase activity. (1, 3, 5 e $10 \mathrm{mg} / \mathrm{mL})$ and positive acarbose control $(0.5 \mathrm{mg} / \mathrm{mL})$, and the concentration was adjusted to a final concentration of $1 ; 10 ; 20 ; 40 ; 80 ; 160 \mu \mathrm{g} / \mathrm{mL})$.

The concentration capable of inhibiting $50 \%$ of enzymatic activity $\left(\mathrm{IC}_{50}\right)$ was calculated from the inhibition value obtained from the serial dilution of the polysaccharide, expressed in a dose-response curve $(1-10 \mathrm{mg} / \mathrm{mL})$.

\subsection{Determination of antibacterial activity}

The Minimum Inhibition Concentration (MIC) of fungal polysaccharide against Staphylococcal aureus ATCC 29213, Klebsiela pneumoniae ATCC 25922, Pseudomonas aeruginosa ATCC 27853, Escherichia coli ATCC 25922 and Proteus mirabilis ATCC 17407 were determined by broth microdilution method [32].

After bacteria growth in nutrient broth for $24 \mathrm{~h}$ to $37^{\circ} \mathrm{C}$, they were diluted in nutrient broth to $10^{5} \mathrm{CFU} / \mathrm{mL}$ and incubated with polysaccharides $(1,3,6,10 \mathrm{mg} / \mathrm{mL})$ for $24 \mathrm{~h}$ to $37^{\circ} \mathrm{C}$ in microplates. After, resazurine $(0.01 \%)$ was added to the suspension and the MIC was determined as the lowest concentration where there was no bacterial growth after $1 \mathrm{~h}$, indicated by the blue color.

Statistical analysis

The results on amylase activity were compared with acarbose by ANOVA and Dunnett's post-test with significance level of 5\% using for Program Graphpad Prism 5.0.

\section{Results and Discussion}

The fungus Periconia byssoides CCMB 07.07 showed biomass production of $2.154 \pm 0.020 \mathrm{~g} / 100 \mathrm{~mL}$ of medium. Fang and Zhong (2002) observed biomass production value of the fungus Ganoderma lucidum of $1.67 \mathrm{~g} / 100 \mathrm{~mL}$ of medium. By analyzing the biomass production of the fungus Pleurotus sajor-cashew also through submerged fermentation, Confortin (2006) obtained a lower value than the present research $(0.257 \mathrm{~g} / 100 \mathrm{~mL}$ of medium). Lee et al. (2013) obtained value s higher than the above-mentioned studies, observing biomass production equal to $2.31 \mathrm{~g} / 100 \mathrm{~mL}$ of medium when analyzing the fermentation of the fungus Paecilomyces japonica.

The analysis of the content of total sugars and reducers sugars of the polysaccharides of $P$. byssoides were used to obtain the number-average molecular weight (MWn) and degree of polymerization (DPn), with values equal to $5.7 \times 10^{4} \mathrm{Da}$ and 352, respectively. Hashemifesharaki et al. (2020) when studying the molar mass of a polysaccharide observed a slightly lower value $\left(4.87 \times 10^{4} \mathrm{Da}\right)$ than that of the polysaccharide analyzed in this study. Nuerxiati et al. (2019) obtained two polysaccharides in his research, which shows a molar mass of 25.57 and $11.64 \mathrm{kDa}$. The polysaccharide purification was conducted in a column $(48 \times 1.2 \mathrm{~cm})$ of Sephacryl S-200 and it was possible to observe the presence of two symmetrical peaks (Figure 1). 
Figure 1. Elution of polysaccharide from P. byssoide in Sephacryl S-200 with $50 \mathrm{mM}$ sodium phosphate (pH 7.0). Fractions $(2.5 \mathrm{~mL})$.

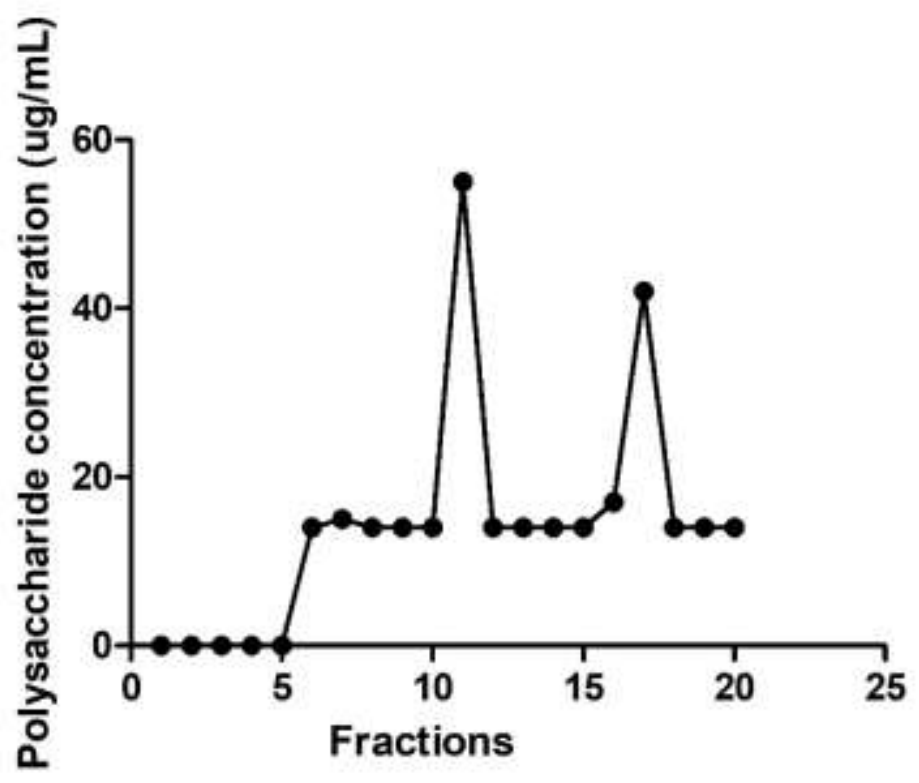

Source: Authors.

The antibacterial and hypoglycemic activities of $P$. byssoides were analyzed with peak 1 of $P$. byssoides (fractions 515). The results shows that this polysaccharide exhibit good inhibition of the enzyme $\alpha$-amylase (72.3\%) concentration of 10 $\mathrm{mg} / \mathrm{mL}$ and $\mathrm{IC}_{50}$ equal to $3.316 \mathrm{mg} / \mathrm{mL}$. In addition, a significant difference was observed between all doses tested and acarbose, a positive control, as can be seen in Figure 2.

Figure 2. Inhibition of the enzyme $\alpha$-amylase by the polysaccharide of $P$. byssoides.

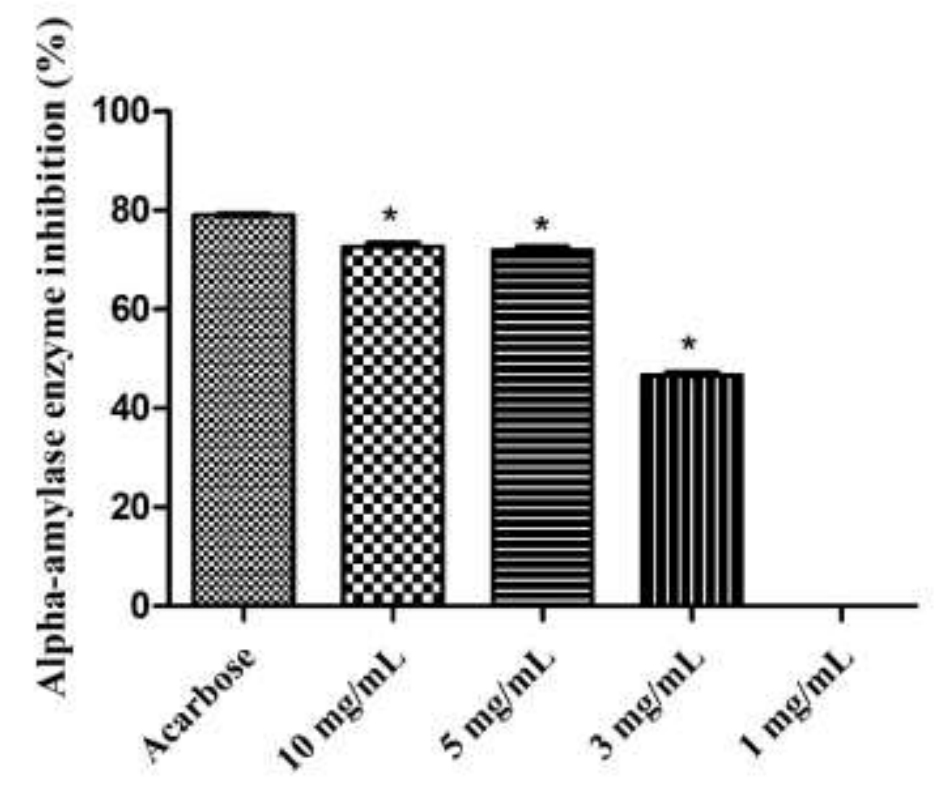

${ }^{*} \mathrm{p}<0.05$, when compared with acarbose by ANOVA and Dunnet post test. The dose of Acarbose tested was $60 \mu \mathrm{g} / \mathrm{mL}$. Source: Authors. 
A study published in 1980 showed that valienamine, a pseudo sugar isolated from fungal cultures, is a potent inhibitor of $\alpha$-glucosidase, besides being one of the components of acarbose, a potent hypoglycemic agent (LAUBE et al., 1980). In addition, more current studies have also linked polysaccharides to hypoglycemic activity. Indeed, Yuan et al. (2020) showed that polysaccharides significantly reduced fasting blood glucose levels in mice with type 2 diabetes mellitus. Additionally, Ru et al. (2020) observed that a selenized polysaccharide reduced blood glucose levels and increased insulin levels, being considered a promising hypoglycemic compound.

Wu et al. (2016) isolated polysaccharides from green tea (Camellia sinensis) and detected that the acid polysaccharide obtained showed an inhibiting activity of around $65 \%$ in relation to $\alpha$-amylase. Wang et al. (2018) isolated three fractions of acid polysaccharides of the species Inonotus obliquus and observed that these fractions strongly inhibited the enzymes $\alpha-$ amylose and $\alpha$-glycosidase.

Researches with fungal metabolites are important due the possibility can lead to new therapies for the treatment of diabetes. A non-peptide fungal metabolite (L-783,281), for example, was isolated from the endophytic fungus Pseudomassaria sp., collected in a forest in the Democratic Republic of Congo (Strobel* and Daisy, 2003). Oral administration of this polysaccharide in two animal models of diabetes significantly reduced serum glucose levels. In addition, these compost acts as mimetic insulin and, unlike insulin, is not destroyed in the digestive tract, and can be administered orally (ZHANG et al., 2007).

On the other hand, the polysaccharide of $P$. byssoides did not present antibacterial potential against the evaluated strains (S. aureus, K. pneumoniae, P. aeruginosa, E. coli and P. mirabilis), because at the maximum tested concentration (10 $\mathrm{mg} / \mathrm{mL}$ ) the bacteria showed growth. Sharma et al. (2016) showed that the aqueous extract of the fungus Lentinula edodes showed small antibacterial activity against the bacteria Acinetobacter sp., E. coli, Klebsiella pneumoniae, Salmonella typhii and Vibrio cholerae.

Here, the antiproliferative activity of polysaccharide obtained from the fungus $P$. byssoides was also evaluated, however no such activity was observed in the tested concentration.

\section{Conclusion}

The results showed that the polysaccharide of P. byssoides has potential as hypoglycemic. Therefore, it would be valuable to perform in vivo studies with this polysaccharide aiming to confirm its hypoglycemic activity.

\section{References}

Badel, S., Bernardi, T., \& Michaud, P. (2011) New perspective for Lactobacilli exopolysaccharides. Biotechnology Advances, $29: 54-66$.

Barroso, P. A. et al. (2007). A trial of immunotherapy against Leishmania amazonensis infection in vitro and in vivo with Z-100, a polysaccharide obtained from Mycobacterium tuberculosis, alone or combined with meglumine antimoniate. Journal Antimicrobiology Chemotheraphy, 59: 1123-1129.

Cheng, J-J. et al. (2014). Studies on anti-inflammatory activity of sulfated polysaccharides from cultivated fungi Antrodia cinnamomea. Food Hydrocolloids, 53: $37-45$.

Clinical and Laboratory Standards Institute: Methods for dilution antimicrobial susceptibility tests for bacteria that grow aerobically, approved standard. 2006, CLSI, Wayne, PA, USA, CLSI document M07-A7, 7.

Du, B. et al. (2015). An insight into anti-inflammatory effects of fungal beta-glucans. Trends in Food Science \& Technology, 41: 49-59.

De Vuyst, L. \& Degeest, B. Heteropolysaccharides from lactic acid bacteria. FEMS Microbiology Reviews, 25, $153-177$.

Dong, Caihong et al. Application of Box-Behnken design in optimization for polysaccharides extraction from culturedmycelium of Cordyceps sinensis. Food and Bioproducts Processing, 87(2), 139-144.

Dubois, M. et al. Colorimetric method for determination of sugars and related substances. Analytical Chemistry, 28(3), 350-356.

Ehmann, H. et al. Gold nanoparticles in the engineering of antibacterial and anticoagulant surfaces. Carbohydrate Polymers, 117, 34-42. 
Ebrahimiasl, S. et al. (2015). Novel conductive polypyrrole / zinc oxide / chitosan bionanocomposite: synthesis, characterization, antioxidant, and antibacterial activities. International Journal of Nanomedicine, 10: 217-227.

Fang, Quing-Hua, Zhong, Jian-Jiang. (2002). Effect of initial pH on production of ganoderic acid and polysaccharide by submerged fermentation of Ganoderma lucidum. Process Biochememistry, 37: 769- 774.

Fu, H. et al. (2015). Immunomodulatory activities on raw 264.7 macrophages of a polysaccharide from veiled lady mushroom, Dictyophora indusiata (higher basidiomycetes). International Journal of Medicinal Mushrooms, 17: 151-160.

Fukuda, E. K. et al. (2009). Fungal cell wall polysaccharides: purification and characterization. Semina: Agrarian Sciences, $30: 117-134$.

Giese, E. et al. (2015). Free-radical scavenging properties and antioxidant activities of botryosphaeran and some other $\beta$-D-glucans. International Journal of Biological Macromolecules, 72: 125-130.

Hashemifesharaki, R. et al. (2020). Microwave-assisted extraction of polysaccharides from the marshmallow roots: Optimization, purification, structure, and bioactivity. Carbohydrate Polymers, 240: 1-9.

Kumar, S. P. et al. (2015). Antioxidant studies of chitosan nanoparticles containing naringenin and their cytotoxicity effects in lung cancer cells. International Journal of Biological Macromolecules, 78: 87-95.

Kumar, S.et al. (2015). Extremophilic polysaccharide nanoparticles for cancer nanotherapy and evaluation of antioxidant properties. International Journal of Biological Macromolecules, 76: 310-319.

Laube, H. (1980). Effect of glucosidase inhibitor, Bay g 5421 (acarbose), on the blood glucose in obese diabetic patients type 2 (NIDDM). ArzneimittelForschung, 30: 1154-1157.

Lazaridou, A. et al. (2014). Structure development and acidification kinetics in fermented milk containing oat $\beta$-glucan, a yogurt culture and a probiotic strain. Food Hydrocolloids, 39: 204-214

Lee, J. S. et al. (2013). Culture conditions and medium components for the production of mycelial biomass and exo-polysaccharides with Paecilomyces japonica in liquid culture. Journal of Bioscience and Bioengineering, 115: 433-437.

Liu, Y. et al. (2014). preparation, antiangiogenic and antitumor activities of the chemically sulfated glucan from phellinus ribis. carbohydrates polymers, 106: $42-48$.

Mahapatra, S., \& Banerjee, D. (2013). Fungal exopolysaccharide: production, composition and applications. Microbiology insights, 6: 1-16.

Maity, P. et al. (2015). Structural, immunological, and antioxidant studies of $\beta$-glucan from edible mushroom Entoloma lividoalbum. Carbohydrate polymers, 123: $350-368$.

Noleto, W. et al. (2002). Effects of a lichen galactomannan and its vanadyl (IV) complex on peritoneal macrophages and leishmanicidal activity. Molecular and Cellular Biochemistry, 233: 73-83.

Nogueira, F.A. et al. (2014). Efficacy of aqueous extracts of Genipa americana L. (Rubiaceae) in inhibiting larval development and eclosion of gastrointestinal nematodes of sheep. Journal of Applied Animal Research, 42: 356-360.

Nuerxiati, R. et al. (2019). Optimization of ultrasonic-assisted extraction, characterization and biological activities of polysaccharides from Orchis chusua D. Don (Salep). International Journal of Biological Macromolecules, 141: 431-443.

Oliveira, L. D. R. et al. (2012). Haemonchus contortus: in vivo anthelmintic activity of Genipa americana L. leaves in sheep. Medica Plant, v. 78.

Wang, J. et al. (2017). Emerging roles of Ganoderma Lucidum in anti-aging. Aging and Disease, 8: 691-707.

$\mathrm{Ru}$, Y. I., et al. (2020). synthesis of selenylated polysaccharides from momordica charantia 1 . and its hypoglycemic activity in streptozotocin-induced diabetic mice. International Journal of Biological Macromolecules, 152: 295-304.

Rojas, J. et al. Screening for antimicrobial activity of ten medicinal plants used in Colombian folkloric medicine: A possible alternative in the treatment of non-nosocomial infections. BMC Complementary and Alternative Medicine, 6: 1-6.

Ruthes, A. C., et al. (2013). Fucomannogalactan and glucan from mushroom Amanita muscaria: Structure and inflammatory pain inhibition. Carbohydrate Polymers, 98: 9761- 769 .

Souza, R. O. S. et al. (2018). Trypanocidal activity of polysaccharide extract from Genipa americana leaves. Journal Ethnopharmacology. 10: 311 -331.

Sharafbafi, N. et al. (2014). Phase behaviour, rheological properties, and microstructure of oat $\beta$-glucan-milk mixtures. Food Hydrocolloids, 41: 274-280.

Sharma, S., Sharma, V., \& Kuila, A. (2016). Cellulase production using natural medium and its application on enzymatic hydrolysis of thermo chemically pretreated biomass. 3 Biotech, 6: 139 .

Strobel, G., \& Daisy, B. (2003). Bioprospecting for microbial endophytes and their natural products. Microbiology and molecular biology reviews: MMBR, 67(4), 491-502. https://doi.org/10.1128/MMBR.67.4.491-502.2003

Tian, S. et al. (2017). Optimization conditions for extracting polysaccharide from Angelica sinensis And Its Antioxidant Activities. Journal of Food and Drug Analysis, 25: 766-775. 
Research, Society and Development, v. 10, n. 12, e493101218433, 2021

(CC BY 4.0) | ISSN 2525-3409 | DOI: http://dx.doi.org/10.33448/rsd-v10i12.18433

Vasconcelos, A. F. et al. (2013). Sulfonation and anticoagulant activity of fungal exocellular $\beta-(1 \rightarrow 6)-\mathrm{D}-$ glucan (lasiodiplodan). Carbohydrate Polymers, 92 : 1908-1914,

Vettori, M. H. P. B. et al. (2012) Structural characterization of a new dextran with a low degree of branching produced by Leuconostoc mesenteroides FT045B dextransucrase. Carbohydrate polymers, 88: 1440-1444.

Wang, J. et al. (2017). Emerging roles of Ganoderma lucidum in anti-aging. Aging Disease, 8: 691-707.

Welman, A., \& Maddox, I. (2003). Exopolysaccharides from lactic acid bacteria: perspectives and challenges. Trends in Biotechnology, 21: 269-274.

Wasser, S. (2015). Medicinal mushroom science: current perspectives, advances, evidences, and challenges. Biomedical Journal, 37: 345-356.

Wang, Y. et al. (2010). Physical characterization of exopolysaccharide produced by Lactobacillus plantarum KF5 isolated from Tibet Kefir. Carbohydrate Polymers, 82: 895-903.

$\mathrm{Wu}, \mathrm{Z}$. et al. (2016). Extraction, characterization and antioxidant activity of mycelial polysaccharides from Paecilomyces hepiali HN1. Carbohydrate polymers, 137: 541-548.

Yu, Y. et al. (2017). Biological activities and pharmaceutical applications of polysaccharide from natural resources: A review. Carbohydrate Polymers, 183: 91-101.

Ye, S. et al. (2012). Antioxidant activities of an exopolysaccharide isolated and purified from marine Pseudomonas PF-6. Carbohydrate Polymers, 87: 764770.

Yamada, T. et al. (2007). Pericosines, antitumor metabolites from the sea hare-derived fungus Periconia byssoides. Structures and biological activities. Organic and Biomolecular Chemistry, 5: 3979-3986.

Yuan, Y. et al. (2020). Beneficial effects of polysaccharide-rich extracts from Apocynum Venetum leaves on hypoglycemic and gut microbiota in type 2 diabetic Mice. Biomedicine \& Pharmacotherapy, 127: 1-9.

Zimmermann, M. (1983). Ethical guidelines for investigations of experimental pain in conscious animals. Pain, 16: 109-110.

Zhang, N. et al. (2014). Application of Box-Behnken design in optimization of allelopathic effects of Potamogeton pectinatus against Microcystis aeruginosa. Transactions of Tianjin University, 20: 344-349.

Zhang, M. et al. (2014). Antitumor polysaccharides from mushrooms: a review on their isolation process, structural characteristics, and antitumor activity. Trends in Food Science \& Technology, 18: 4-19. 